Træen, B., Carvalheira, A. A., Kvalem, I. L., Hald, G. M. (2018). European older adults' use of the Internet and social networks for love and sex. Cyberpsychology: Journal of Psychosocial Research on Cyberspace, 12(3), article 1. http://dx.doi.org/10.5817/CP2018-3-1

\title{
European older adults' use of the Internet and social networks for love and sex
}

\author{
Bente Træen ${ }^{1}$, Ana Alexandra Carvalheira², Ingela Lundin Kvalem¹, \& Gert Martin Hald³ \\ 1Department of Psychology, University of Oslo, Oslo, Norway \\ ${ }^{2}$ Department of Clinical Psychology, University Institute of Psychological and Social Sciences, Lisbon, Portugal \\ ${ }^{3}$ Department of Public Health, University of Copenhagen, Copenhagen, Denmark
}

\begin{abstract}
What is the prevalence of using the Internet for love and sexual activities among older adults across Europe, and what predicts such use? Data were collected in probability samples among populations aged 60-75 years in Norway $(N=1271)$, Denmark $(N=1045)$, Belgium $(N=991)$, and Portugal $(N=509)$ using postal questionnaires. $A$ total of $36 \%$ of men and $15 \%$ of women reported having used the Internet for sex and love purposes, most often to watch pornography. The use of the Internet for various love and sex purposes was higher in participants who had a partner, who had masturbation activity and who were satisfied with their current level of sexual activity. Multivariate logistic regression analyses showed that use of the Internet to find committed partners, watch pornography, buy sex products or seek information or advice was lower in Portuguese men than men in Norway, Denmark, and Belgium. Tailored websites to promote both sexuality and how to preserve a committed relationship are likely to prove important for the aging population.
\end{abstract}

Keywords: Older adults; Internet; online sexual activity; dating; Europe; cross-cultural studies

\section{Introduction}

In 2016, $82 \%$ of Europeans used the Internet at least once a month and $71 \%$ were daily users (Eurostat, 2018). In the four European countries where the current study was conducted, weekly use was registered in $96 \%$ of Norwegian, $94 \%$ of Danish, $79 \%$ of Belgian, and $68 \%$ of Portuguese individuals. Furthermore, $57 \%$ of Europeans aged 55-74 years reported being daily Internet users compared to $96 \%$ of $16-24$-year-olds, with higher-educated individuals being more frequent daily users than lower-educated individuals (96\% versus 60\%) (Eurostat, 2018).

Research literature on how common it is for older adults to engage in Internet activities related to love and sexuality purposes is sparse. Cooper, Morahan-Martin, Mathy, and Maheu (2002) assert that Internet love and sexual activities can take on a variety of forms including recreational and educational activities, entertainment, purchasing of sexual materials, partner searches, sexual arousal, sharing of erotica, and cybersex.

On a general level, five factors are important in making the Internet a powerful medium for love and sex purposes (Cooper, 1998; King, 1999; Ross \& Kauth, 2002): access, affordability, anonymity, acceptability, and approximation. Further, the use of the Internet for love or sexual purposes is shown to fall into two main groups (Cooper, Månsson, Daneback, Tikkanen, \& Ross, 2003; Carvalheira \& Gomes, 2003): a) 'seeking partners' (finding partners for offline love and/or sexual relationships or meetings) and b) 'accessing erotica' (reading erotic novels or viewing pornographic or erotic pictures and movies). 
According to Cooper et al. (2003), using the Internet to view pornographic pictures and movies is, by far, the most popular online sexual activity for men of all ages (Short, Black, Smith, Wetterneck, \& Wells, 2012). For instance, statistics from one of the world's largest porn websites, 'Pornhub', showed that, in 2016, 26\% of visitors were women, with little variation across countries, and the age group of 55 years or older constituted $11 \%$ of the visitors (7\% of $55-64-y e a r-o l d s$ and $4 \%$ of those aged $65+$ years).

In a Portuguese sample of chat users (313 men, 46 women), Carvalheira and Gomes (2003) found chats served as a starting place for offline relationships. The online anonymity reduced fear of rejection and social sanctions, creating a context where the participants felt free to express their desires and interests. Træen and Daneback (2012) found that, among Norwegian heterosexual people aged 18-67 years, more men (65\%) than women (29\%) reported using the Internet for love and sexual purposes. While it was most common for men to watch pornography, it was more common for women to seek advice and information about sexual matters (35\%) on the Internet. This indicated a gender difference in how the Internet is used for love and sexual activities that, to our knowledge, has not been further explored or quantitatively qualified for older generations of Internet users.

Træen and Daneback (2012) found that 18-67-year-old men and women who were highly sexually active used Internet pornography more often during masturbation than others. Based on this, it can be expected that older adults who have been more sexually active throughout their lives, and who are still sexually active, will be more likely to use the Internet for love and sex purposes. Further, Træen and Daneback's study revealed that men who were dissatisfied and women who were satisfied with their sex lives used more pornography during masturbation than those who were satisfied (men) and unsatisfied (women). This indicates that men who are dissatisfied with their sex life may use pornography as a compensation or alternative to an unsatisfactory sex life. In women, on the other hand, the use of pornography seems to come in addition to an already well-functioning sex life. Whether these findings are also valid for older adults and across European countries is unknown. The findings from the present study will contribute to filling this gap in the literature.

Just like younger adults, older adults may be checking websites to find a new partner or for solo sex purposes. This may be more prevalent among older age individuals without a partner as compared with older age individuals with a partner (McWilliams \& Barrett, 2012; Wion \& Loeb, 2015). Investigating the impact of relationship status on the use of the Internet for partner or solo sex purposes among older age individuals may help to further qualify this.

Albright and Conran (2003) analysed the narratives of 366 participants to understand how relationships develop through the Internet and identified three steps: 1) falling in love, 2) meeting of minds-a quick intimacy and emotional bonding, and 3) virtual mirror-mutual idealization and optimization. Studies revealed that relationships through the Internet are characterized by high levels of intimacy and self-disclosure (Albright \& Conran, 2003; Bargh, McKenna, \& Fitzsimons, 2002; Carvalheira, 2005; Cooper \& Sportolari, 1997; Joinson, 2001; Kim \& Dindia, 2011; McKenna, Green, \& Gleason, 2002). However, online self-disclosure seems to be less common in older age groups (Kim \& Dindia, 2011). In the context of older age cohorts, an Australian study (Malta, 2007) analysed relationships among older adults (61-85 years) who had all used the Internet to meet potential romantic partners. For the most part, the relationships described were meaningful, intimate, and long-lasting. The majority of participants were involved in ongoing sexual activity with their partners, and, for some, cyber-sex was or had been an integral part of their relationships. Additionally, a proportion enjoyed flirting online with others, and some were also involved in extra-dyadic relationships. However, more cross-cultural research exploring the prevalence of older age adult who use the Internet to find partners and what predicts such partner seeking is needed to further qualify and explore these findings.

From a public health perspective among older age generations, exploring the extent to which the Internet is used to seek sexual advice and information or, sexuality counselling may be helpful in qualifying if the Internet can be used to reach the older age generation and enhance sexual health and well-being. Using data from the European study of healthy sexual aging (Træen, et al., 2018), this paper aims to comparatively address the use of the Internet for love and sexual purposes across four European countries using large samples of individuals aged 60-75 years and, further, to gauge the extent to which sociodemographic factors and sexual activity predict such usage. Accordingly, the study posed the following two research questions: 
1. What is the prevalence of using the Internet for love and sex purposes among 60-75-year-olds in Norway, Denmark, Belgium, and Portugal, and which activities are they engaging in?

2. What is the relationship between using the Internet to find a committed partner, seek sexual information or advice, read or watch pornography, or buy sex products and sociodemographic factors (age, level of education, relationship status) and sexual perceptions and activities (masturbation frequency, satisfaction with current level of sexual activity, sexual activity throughout life)?

\section{Methods}

\section{Participants}

The Department of Psychology at the University of Oslo, in cooperation with the poll organization IPSOS (Institut de Publique Sondage d'Opinion Secteur), conducted a multinational survey on the sexual lives of 60-75-year-olds in probability samples of the population in Norway, Denmark, Belgium, and Portugal. The sample size in Norway was $n=1271$, in Denmark $n=1045$, in Belgium $n=991$, and in Portugal $n=509$.

\section{Procedure and Recruitment}

Initially, IPSOS conducted a recruitment interview by telephone to a nationally representative sample of the population 60-75 years old. Those who accepted participation received an anonymous postal questionnaire. This method of data collection was chosen based on previous studies on potentially sensitive topics.

The questionnaire, which consisted of 66 main questions, was developed in English and subsequently translated into local languages. Most of the included questions and scales in the questionnaire were adapted from previous studies among the target group, for instance from NATSAL-3 (Mitchell et al., 2013). An overview of the included questions and scales is given elsewhere (Træen et al., 2018).

The questionnaire was developed in English and subsequently translated into local languages translated by the principal investigators and persons employed by IPSOS in each country. After the translation of into native languages was finalized, randomized telephone recruitment of participants started from October to December 2016. Trained interviewers at IPSOS made the phone calls after guidance. Using national phone registries (with the exception of Portugal), the sampling procedure would potentially produce probability samples of the target population. Portugal differed from Norway, Denmark, and Belgium in that there are several problems with regard to drawing a telephone sample from the population of 60-75-year olds. For example, a complete and updated telephone register does not exist in Portugal. For this reason, IPSOS used the 'common routine' for telephone surveys in Portugal when recruiting as follows: 1) telephone numbers were first randomly selected from fixed phone directories and IPSOS's own database of phone numbers; 2 ) to obtain a distribution representative of the population, participants were selected by age and gender; and 3) due to illiteracy problems, participants who had not completed primary school (ISCED 1) were excluded from the sample. Ethics approval was handled by IPSOS in accordance with European standards. The ethical procedures followed the standards of ESOMAR (The European Society for Opinion and Market Research), as stated in the general contract with the University of Oslo. By the standards of ESOMAR, IPSOS is obliged to follow national and international rules and guidelines for what is recognized as professionally sound market analysis. The rules comprise treatment of confidentiality, respondent anonymity, questionnaires and databases and methods for data collection etc. It is also referred to the ethical rules for The Norwegian Association of Marketing and Opinion Research. No compensation for participation was given.

The study was conducted as a postal survey among all who agreed to participate in the telephone interview. The questionnaires were sent back by a freepost envelope to return the completed questionnaire. Two reminders were sent starting one week after the questionnaire was received. After a discussion with IPSOS in Portugal, it was decided to do the reminders by phone. Unfortunately, 502 potential participants could not be reached by phone. Of the 1498 individuals contacted by phone, 561 refused to participate after having seen the questionnaire. Overall, the response rates were 68\% in Norway, 52\% in Denmark, 57\% in Belgium, and 26\% in Portugal. 


\section{Measures}

\section{Dependent variable.}

Internet activity was assessed by the question, 'What activities related to love and sexuality do you engage in on the Internet (tick all that apply)?' The sub questions were: 'Using social media such as Facebook or Twitter to find a committed partner', 'Checking dating sites to find a committed partner', 'Using social media such as Facebook or Twitter to find a partner for sex', 'Checking dating sites to find sex partners', 'Seeking sexuality counselling', 'Seeking information or advice', 'Reading or watching erotica or pornography', 'Buying sex products (sex-toys, erotica, Viagra, lubricants, etc.)', and 'Other'. All 'ticks' were coded as $1=$ 'use' and $0=$ 'no use'.

\section{Independent variables.}

Age was measured as a continuous variable in years.

Level of education was assessed as the highest level of formal education. In three countries, the response categories were $1=$ Primary school (6-8 years at school), $2=$ Lower secondary school $(9-10$ years at school), $3=$ Higher secondary school, high school (12-13 years at school), 4 = College, lower university level (bachelor's degree level or similar), and $5=$ Higher university level (master's degree, PhD or similar). In Belgium, additional response alternatives were added to mirror the educational system in the country. To allow for cross-cultural comparisons, the variable was recoded into $1=$ primary (1), $2=$ secondary $(2+3)$, and $3=$ tertiary education $(4+5)$.

Relationship status was assessed with the question 'Do you currently have a steady/committed relationship with anybody? A steady/committed relationship also includes married/cohabiting persons. The response categories were $1=$ Yes, $2=\mathrm{No}$, and $3=$ Unsure. The 21 participants who were unsure about their relationship status were included in the 'No' category.

Sexual activity throughout life was measured with the question 'In your lifetime, how would you rate your sexual activity throughout most of your life (until the age of 60 )?' The response categories were $1=1$ was sexually very active, 2 = I was moderately sexually active, $3=$ Neither active nor inactive, $4=$ I was moderately sexually inactive, and $5=1$ was very sexually inactive. The variable was recoded into $1=$ Active, $2=$ Neither, and $3=$ Inactive.

Satisfaction with the current level of sexual activity was assessed with the question 'How satisfied are you with the current level of sexual activity in your life in general?' Response options for the question were 1 = Very satisfied, 2 $=$ Rather satisfied, $3=$ Neither satisfied nor dissatisfied, $4=$ Rather dissatisfied, and $5=$ Very dissatisfied. The variable was recoded into $1=$ Satisfied, $2=$ Neither, and $3=$ Dissatisfied.

Masturbation activity was assessed with the question 'How often did you masturbate in the past month?' Response options for the question were $1=$ None, 2 = Once in the past month, $3=2$ or 3 times in the past month, $4=$ Once a week, $5=2$ or 3 times a week, $6=$ Once a day, and $7=$ More than once a day. The variable was recoded into $1=$ None, 2 = Monthly, and 3 = Weekly or daily.

\section{Statistical Analysis}

Using SPSS 24.0, bivariate and multivariate logistic regression analyses were carried out on weighted data (DuMouchel \& Duncan, 1983). Based on census data, weighting was used to adjust for the unequal probabilities of selection in terms of age and gender. All data analyses were performed separately for men and women to avoid intercorrelations due to inclusion of heterosexual couples. For each country, we used binary logistic regression to calculate age-adjusted odds ratios to investigate how reporting of the outcome variable varied by the predictors. To reduce the chance of Type I errors, the level of significance was set to $p<.01$. For comparison purposes, significance levels of $p<.05$ are included in Tables 3-4, but not commented upon in the text. 


\section{Results}

The mean age of men was 66.7 years in Norway, 67.8 in Denmark, 67.3 in Belgium, and 66.6 in Portugal. In women, the mean age was 66.9 years in Norway, 67.8 in Denmark, 66.4 in Belgium, and 66.8 in Portugal. The sociodemographic characteristics of the samples are presented in Table 1. Table 1 also reports the percentage of the participants who said they used the Internet for some kind of love and sex activities. Of all participants, 35.5\% of men and $14.5 \%$ of women reported having used the Internet for sex and love purposes. More men from Norway and Belgium than from Portugal and Denmark reported having used the Internet for sex or love purposes. In women, no significant difference in use was found.

Table 1. Sociodemographic Characteristics, and Percent of Men and Women from Norway, Denmark, Belgium and Portugal Who Use the Internet for Activities Connected to Love and Sex (Weighted Data).

\begin{tabular}{|c|c|c|c|c|c|c|c|c|c|c|}
\hline & \multicolumn{5}{|c|}{ Men } & \multicolumn{5}{|c|}{ Women } \\
\hline & Norway & Denmark & Belgium & Portugal & Sign. & Norway & Denmark & Belgium & Portugal & Sign. \\
\hline & $\%$ & $\%$ & $\%$ & $\%$ & & $\%$ & $\%$ & $\%$ & $\%$ & \\
\hline Age groups & & & & & $\star \star \star$ & & & & & $\star \star \star$ \\
\hline $60-64$ yrs & 35.8 & 27.2 & 28.6 & 36.2 & & 35.5 & 28.2 & 38.2 & 34.7 & \\
\hline $65-69$ yrs & 34.7 & 31.7 & 37.4 & 34.9 & & 34.0 & 31.8 & 33.7 & 36.1 & \\
\hline \multirow[t]{2}{*}{$70-75$ yrs } & 29.5 & 41.1 & 34.0 & 28.9 & & 30.5 & 40.0 & 28.1 & 29.2 & \\
\hline & $(n=634)$ & $(n=523)$ & $(n=486)$ & $(n=232)$ & & $(n=636)$ & $(n=522)$ & $(n=505)$ & $(n=277)$ & \\
\hline Level of education & & & & & 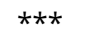 & & & & & $\star \star *$ \\
\hline Primary & 10.6 & 28.6 & 11.1 & 34.5 & & 9.3 & 26.3 & 13.1 & 42.5 & \\
\hline Secondary & 33.3 & 36.3 & 49.4 & 47.0 & & 40.5 & 38.8 & 53.2 & 41.8 & \\
\hline \multirow[t]{2}{*}{ Tertiary } & 56.2 & 35.1 & 39.5 & 18.5 & & 50.2 & 34.8 & 33.7 & 15.8 & \\
\hline & $(n=634)$ & $(n=518)$ & $(n=486)$ & $(n=232)$ & & $(n=634)$ & $(n=520)$ & $(n=498)$ & $(n=273)$ & \\
\hline Place of residence & & & & & $\star \star \star$ & & & & & $\star \star \star$ \\
\hline Rural & 35.3 & 36.5 & 21.6 & 20.8 & & 33.2 & 34.5 & 26.7 & 23.5 & \\
\hline Small town & 37.0 & 34.6 & 51.1 & 25.5 & & 38.0 & 35.7 & 39.1 & 19.1 & \\
\hline Medium sized city & 12.0 & 14.0 & 10.6 & 20.8 & & 12.3 & 13.0 & 13.6 & 20.6 & \\
\hline Suburb of a large city & 6.3 & 7.1 & 10.6 & 7.8 & & 5.1 & 6.5 & 11.5 & 6.6 & \\
\hline Central large city & 9.2 & 7.3 & 5.2 & 24.2 & & 10.5 & 9.3 & 5.9 & 29.0 & \\
\hline \multirow[t]{2}{*}{ Other } & 0.2 & 0.4 & 0.8 & 0.9 & & 1.0 & 1.0 & 3.2 & 1.1 & \\
\hline & $(n=632)$ & $(n=520)$ & $(n=481)$ & $(n=231)$ & & $(n=627)$ & $(n=507)$ & $(n=494)$ & $(n=272)$ & \\
\hline Relationship status & & & & & $\star \star \star$ & & & & & 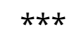 \\
\hline Partnered & 82.3 & 83.6 & 79.2 & 92.7 & & 69.3 & 84.5 & 46.8 & 73.3 & \\
\hline \multirow[t]{2}{*}{ No partner } & 17.7 & 16.4 & 20.8 & 7.3 & & 30.7 & 15.5 & 53.2 & 26.7 & \\
\hline & $(n=631)$ & $(n=523)$ & $(n=485)$ & $(n=232)$ & & $(n=635)$ & $(n=521)$ & $(n=504)$ & $(n=277)$ & \\
\hline
\end{tabular}

\begin{tabular}{lrrrr} 
Religious affiliation & & & & \\
None & 34.3 & 16.7 & 35.1 & 15.3 \\
Christian, no denomination & 29.9 & 48.1 & 20.0 & 22.7 \\
Roman Catholic & 0.6 & 1.3 & 43.5 & 56.8 \\
Protestant & 31.2 & 33.0 & 0.4 & 0.0 \\
Free church etc. & 1.9 & 0.2 & 1.0 & 1.3 \\
Muslim & 0.0 & 0.0 & 0.0 & 0.4 \\
Buddhist & 0.2 & 0.0 & 0.0 & 0.4 \\
Other & 1.9 & 0.8 & 0.0 & 3.1 \\
\hline & $(n=629)$ & $(n=522)$ & $(n=485)$ & $(n=229)$
\end{tabular}

\begin{tabular}{rrrr}
25.1 & 11.3 & 34.7 & 10.6 \\
30.3 & 49.8 & 22.3 & 31.1 \\
1.1 & 0.4 & 40.8 & 54.6 \\
38.2 & 36.2 & 0.4 & 0.4 \\
3.5 & 0.6 & 0.4 & 1.8 \\
0.0 & 0.0 & 0.0 & 0.0 \\
0.0 & 0.0 & 0.2 & 0.0 \\
1.7 & 1.7 & 1.2 & 1.5 \\
\hline$(n=633)$ & $(n=522)$ & $(n=502)$ & $(n=273)$
\end{tabular}

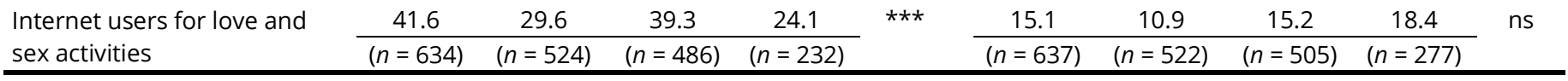
Note: Chi-square test of group differences; Due to possible Type I error, level of significance is set to minimum $p<0.1$. $\star * * p<.001 ; \mathrm{ns}=$ not statistically significant

Table 2 shows the types of activities connected to sex and love in which the participants who had used the Internet for such activities had engaged. In men, it was most common to have used the Internet to read or watch erotica or pornography, buy sex products, or seek information or advice. More men in Norway (74.5\%) than in Portugal 
(39.3\%) had read or watched pornography $(p<.001)$, and more in Portugal $(21.4 \%)$ than in Denmark $(5.8 \%)$ had sought information or advice $(p<.001)$.

In women, it was also most common to have used the Internet to 1) read or watch erotica or pornography, 2) seek information or advice, or 3) check dating sites to find a committed partner. There were only two statistically significant differences in the reporting among women in the four countries. More women in Portugal than in Norway and Denmark had used social media to find a partner for sex $(p<.001)$.

Table 2. Activities Connected to Love and Sex on the Internet among Internet Using Men and Women from Norway, Denmark, Belgium and Portugal (Percent, Weighted Data).

\begin{tabular}{|c|c|c|c|c|c|c|c|c|c|c|}
\hline \multirow[b]{2}{*}{ Percent respondents having } & \multicolumn{5}{|c|}{ Men } & \multicolumn{5}{|c|}{ Women } \\
\hline & Norway & Denmark & Belgium & Portugal & sign & Norway & Denmark & Belgium & Portugal & Sign \\
\hline $\begin{array}{l}\text { Using social media such as } \\
\text { Facebook or Twitter to find a } \\
\text { committed partner }\end{array}$ & $\begin{array}{c}3.8 \\
(n=263)\end{array}$ & $\begin{array}{c}1.3 \\
(n=155)\end{array}$ & $\begin{array}{c}2.1 \\
(n=191)\end{array}$ & $\begin{array}{c}1.8 \\
(n=55)\end{array}$ & ns & $\begin{array}{c}1.1 \\
(n=95)\end{array}$ & $\begin{array}{c}1.8 \\
(n=56)\end{array}$ & $\begin{array}{c}3.9 \\
(n=77)\end{array}$ & $\begin{array}{c}2.0 \\
(n=51)\end{array}$ & ns \\
\hline $\begin{array}{l}\text { Checking out dating sites to } \\
\text { find a committed partner }\end{array}$ & $\begin{array}{c}7.6 \\
(n=264)\end{array}$ & $\begin{array}{c}5.2 \\
(n=155)\end{array}$ & $\begin{array}{c}11.0 \\
(n=191)\end{array}$ & $\begin{array}{c}1.8 \\
(n=56)\end{array}$ & ns & $\begin{array}{c}14.6 \\
(n=96)\end{array}$ & $\begin{array}{c}1.8 \\
(n=57)\end{array}$ & $\begin{array}{c}6.5 \\
(n=77)\end{array}$ & $\begin{array}{c}9.8 \\
(n=51)\end{array}$ & ns \\
\hline $\begin{array}{l}\text { Using social media such as } \\
\text { Facebook or Twitter to find a } \\
\text { partner for sex }\end{array}$ & $\begin{array}{c}1.1 \\
(n=264)\end{array}$ & $\begin{array}{c}1.3 \\
(n=155)\end{array}$ & $\begin{array}{c}0.0 \\
(n=191)\end{array}$ & $\begin{array}{c}0.0 \\
(n=56)\end{array}$ & ns & $\begin{array}{c}0.0 \\
(n=96)\end{array}$ & $\begin{array}{c}0.0 \\
(n=57)\end{array}$ & $\begin{array}{c}1.3 \\
(n=77)\end{array}$ & $\begin{array}{c}9.8 \\
(n=51)\end{array}$ & $* \star *$ \\
\hline $\begin{array}{l}\text { Checking out dating sites to } \\
\text { find sex partners }\end{array}$ & $\begin{array}{c}6.5 \\
(n=263)\end{array}$ & $\begin{array}{c}3.9 \\
(n=155)\end{array}$ & $\begin{array}{c}6.8 \\
(n=191)\end{array}$ & $\begin{array}{c}1.8 \\
(n=56)\end{array}$ & ns & $\begin{array}{c}0.0 \\
(n=96)\end{array}$ & $\begin{array}{c}3.5 \\
(n=57)\end{array}$ & $\begin{array}{c}2.6 \\
(n=77)\end{array}$ & $\begin{array}{c}2.0 \\
(n=51)\end{array}$ & ns \\
\hline $\begin{array}{l}\text { Reading or watching erotica or } \\
\text { pornography }\end{array}$ & $\begin{array}{c}74.5 \\
(n=263)\end{array}$ & $\begin{array}{c}69.0 \\
(n=155)\end{array}$ & $\begin{array}{c}64.4 \\
(n=191)\end{array}$ & $\begin{array}{c}39.3 \\
(n=56)\end{array}$ & $\star \star *$ & $\begin{array}{c}10.4 \\
(n=96)\end{array}$ & $\begin{array}{c}10.7 \\
(n=56)\end{array}$ & $\begin{array}{c}11.7 \\
(n=77)\end{array}$ & $\begin{array}{c}7.8 \\
(n=51)\end{array}$ & ns \\
\hline Seeking sexuality counseling & $\begin{array}{c}2.7 \\
(n=263)\end{array}$ & $\begin{array}{c}5.8 \\
(n=155)\end{array}$ & $\begin{array}{c}2.6 \\
(n=191)\end{array}$ & $\begin{array}{c}8.9 \\
(n=56)\end{array}$ & ns & $\begin{array}{c}0.0 \\
(n=96)\end{array}$ & $\begin{array}{c}5.3 \\
(n=57)\end{array}$ & $\begin{array}{c}3.9 \\
(n=77)\end{array}$ & $\begin{array}{c}0.0 \\
(n=51)\end{array}$ & ns \\
\hline Seeking information or advice & $\begin{array}{c}11.4 \\
(n=264)\end{array}$ & $\begin{array}{c}5.8 \\
(n=155)\end{array}$ & $\begin{array}{c}19.9 \\
(n=191)\end{array}$ & $\begin{array}{c}21.4 \\
(n=56)\end{array}$ & $\star * *$ & $\begin{array}{c}8.3 \\
(n=96)\end{array}$ & $\begin{array}{c}7.0 \\
(n=57)\end{array}$ & $\begin{array}{c}14.3 \\
(n=77)\end{array}$ & $\begin{array}{c}7.8 \\
(n=51)\end{array}$ & ns \\
\hline $\begin{array}{l}\text { Buying sex products (sex-toys, } \\
\text { erotica, Viagra, lubricants etc.) }\end{array}$ & $\begin{array}{c}14.0 \\
(n=264)\end{array}$ & $\begin{array}{c}14.2 \\
(n=155)\end{array}$ & $\begin{array}{c}15.2 \\
(n=191)\end{array}$ & $\begin{array}{c}8.9 \\
(n=56)\end{array}$ & ns & $\begin{array}{c}8.3 \\
(n=96)\end{array}$ & $\begin{array}{c}10.5 \\
(n=57)\end{array}$ & $\begin{array}{c}7.8 \\
(n=77)\end{array}$ & $\begin{array}{c}2.0 \\
(n=51)\end{array}$ & ns \\
\hline Other & $\begin{array}{c}6.8 \\
(n=264)\end{array}$ & $\begin{array}{c}5.2 \\
(n=155)\end{array}$ & $\begin{array}{c}5.2 \\
(n=191)\end{array}$ & $\begin{array}{c}9.1 \\
(n=55)\end{array}$ & ns & $\begin{array}{c}7.3 \\
(n=96)\end{array}$ & $\begin{array}{c}5.4 \\
(n=56)\end{array}$ & $\begin{array}{c}7.8 \\
(n=77)\end{array}$ & $\begin{array}{c}3.9 \\
(n=51)\end{array}$ & ns \\
\hline
\end{tabular}

Note: Chi-square test of group differences; Due to possible Type I error, level of significance is set to minimum $p<0.1$.

$* * * p<.001 ; \mathrm{ns}=$ not statistically significant

Tables 3 and 4 present the results from bivariate contingency analyses and multivariate logistic regression analyses on the four most prevalent use of the Internet for love and sex purposes: a) checking out dating sites to find a committed partner, b) read or watch pornography, c) buying sex products, and d) seek sexual information or advice. Results are stratified by age, level of education, relationship status, sexual activity throughout life, number of times having masturbated in the past month, satisfaction with the current level of sexual activity, and country. 


\begin{tabular}{|c|c|c|c|c|c|c|c|c|c|c|c|c|}
\hline & \multicolumn{3}{|c|}{$\begin{array}{l}\text { Checking out dating sites to } \\
\text { find a partner }\end{array}$} & \multicolumn{3}{|c|}{$\begin{array}{l}\text { Read or watch } \\
\text { pornography }\end{array}$} & \multicolumn{3}{|c|}{$\begin{array}{l}\text { Buying sex } \\
\text { products }\end{array}$} & \multicolumn{3}{|c|}{$\begin{array}{c}\text { Seeking sexual } \\
\text { information or advice }\end{array}$} \\
\hline & $\%$ & AOR & $95 \% \mathrm{Cl}$ & $\%$ & AOR & $95 \% \mathrm{Cl}$ & $\%$ & AOR & $95 \% \mathrm{Cl}$ & $\%$ & AOR & $95 \% \mathrm{Cl}$ \\
\hline \multicolumn{13}{|l|}{$\overline{\text { Age }}$} \\
\hline 60-64 years & $6.3^{*}$ & & & $39.7^{\star \star \star}$ & & & $10.3^{\text {ns }}$ & & & $8.1^{\mathrm{ns}}$ & & \\
\hline $65-69$ years & 3.7 & & & 31.4 & & & 8.5 & & & 6.6 & & \\
\hline 70-75years & 3.3 & & & 26.2 & & & 7.7 & & & 4.9 & & \\
\hline In one year's increase & & $0.91^{* *}$ & $0.86-0.97$ & & $0.97^{*}$ & 0.94-0.99 & & $0.98^{\mathrm{ns}}$ & $0.94-1.02$ & & $0.95^{*}$ & $0.90-0.99$ \\
\hline \multicolumn{13}{|l|}{ Level of education } \\
\hline Primary & $4.9^{*}$ & 1.00 & & $22.6^{* \star *}$ & 1.00 & & $8.3^{\text {ns }}$ & 1.00 & & $4.0^{\mathrm{ns}}$ & 1.00 & \\
\hline Secondary & 5.5 & $0.60^{\mathrm{ns}}$ & $0.30-1.20$ & 31.3 & $1.25^{\mathrm{ns}}$ & $0.88-1.78$ & 8.8 & $0.84^{\mathrm{ns}}$ & $0.52-1.37$ & 7.2 & $1.32^{\text {ns }}$ & $0.69-2.54$ \\
\hline Tertiary & 3.0 & $0.36^{* *}$ & $0.17-0.74$ & 38.0 & $1.25^{\mathrm{ns}}$ & $0.88-1.78$ & 9.1 & $0.74^{\mathrm{ns}}$ & $0.45-1.21$ & 7.0 & $1.43^{\text {ns }}$ & $0.74-2.77$ \\
\hline \multicolumn{13}{|l|}{ Relationship status } \\
\hline Partnered & $2.6^{* \star *}$ & 1.00 & & $31.7^{\mathrm{ns}}$ & 1.00 & & $9.6^{* *}$ & 1.00 & & $6.9^{\mathrm{ns}}$ & 1.00 & \\
\hline Not partnered & 13.2 & $6.26^{* * *}$ & $3.57-10.96$ & 35.6 & $0.81^{\mathrm{ns}}$ & $0.59-1.12$ & 5.0 & $0.54^{*}$ & $0.31-0.96$ & 4.7 & $0.63^{\text {ns }}$ & $0.34-1.16$ \\
\hline \multicolumn{13}{|c|}{ Sexual activity throughout life } \\
\hline Active & $3.7^{* * *}$ & 1.00 & & $32.9^{\text {ns }}$ & 1.00 & & $9.6^{*}$ & 1.00 & & $6.7^{\mathrm{ns}}$ & 1.00 & \\
\hline $\begin{array}{l}\text { Neither active nor } \\
\text { inactive }\end{array}$ & 6.3 & $1.18^{\mathrm{ns}}$ & $0.54-2.58$ & 28.9 & $0.91^{\mathrm{ns}}$ & $0.59-1.40$ & 7.8 & $0.96^{\mathrm{ns}}$ & $0.50-1.83$ & 7.0 & $1.01^{\mathrm{ns}}$ & $0.50-2.05$ \\
\hline Inactive & 15.0 & $1.34^{\mathrm{ns}}$ & $0.61-2.96$ & 39.2 & $0.95^{\mathrm{ns}}$ & $0.55-1.62$ & 1.3 & $0.12^{*}$ & $0.02-0.87$ & 3.8 & $0.45^{\mathrm{ns}}$ & 0.13-1.55 \\
\hline \multicolumn{13}{|c|}{ Number of times masturbated the past month } \\
\hline None & $3.9^{\text {ns }}$ & 1.00 & & $13.3^{* \star *}$ & 1.00 & & $6.8^{* *}$ & 1.00 & & $5.5^{\mathrm{ns}}$ & 1.00 & \\
\hline Monthly & 3.7 & $0.69^{\text {ns }}$ & $0.37-1.27$ & 36.1 & $3.54^{\star \star *}$ & $2.66-4.71$ & 9.3 & $1.53^{*}$ & $1.01-2.32$ & 8.5 & $1.53^{\text {ns }}$ & $0.97-2.41$ \\
\hline Weekly or daily & 6.4 & $0.84^{\mathrm{ns}}$ & $0.45-1.58$ & 63.3 & $11.31^{* * *}$ & $8.29-15.43$ & 12.8 & $2.26^{\star * *}$ & $1.47-3.47$ & 6.4 & $1.14^{\mathrm{ns}}$ & $0.67-1.94$ \\
\hline \multicolumn{13}{|c|}{ Satisfaction with the current level of sexual activity } \\
\hline Satisfied & $3.4^{* * *}$ & 1.00 & & $29.9^{* * *}$ & 1.00 & & $9.8^{\text {ns }}$ & 1.00 & & $6.3^{\text {ns }}$ & 1.00 & \\
\hline Neither nor & 3.2 & $0.43^{*}$ & $0.21-0.88$ & 29.7 & $0.66^{* *}$ & $0.49-0.87$ & 6.6 & $0.63^{*}$ & $0.41-0.96$ & 5.6 & $1.04^{\mathrm{ns}}$ & $0.63-1.70$ \\
\hline Dissatisfied & 7.5 & $1.00^{\mathrm{ns}}$ & $0.54-1.85$ & 40.0 & $0.84^{\text {ns }}$ & $0.63-1.12$ & 9.7 & $0.88^{\text {ns }}$ & $0.58-1.33$ & 8.0 & $1.39^{\text {ns }}$ & $0.86-2.27$ \\
\hline \multicolumn{13}{|l|}{ Country } \\
\hline Norway & $4.3^{* \star *}$ & $8.41^{*}$ & $1.28-55.11$ & $39.0^{* \star *}$ & $3.58^{* \star *}$ & $2.20-5.83$ & $10.1^{*}$ & $2.44^{*}$ & $1.17-5.06$ & $5.2^{* \star *}$ & $0.46^{*}$ & $0.24-0.85$ \\
\hline Denmark & 2.5 & $4.21^{\mathrm{ns}}$ & $0.62-28.66$ & 31.9 & $3.28^{* * *}$ & $2.00-5.37$ & 8.4 & $2.20^{*}$ & $1.05-4.59$ & 2.5 & $0.25^{\star \star \star}$ & $0.12-0.52$ \\
\hline Belgium & 8.2 & $16.25^{* *}$ & $2.51-105.34$ & 33.5 & $3.25^{* * *}$ & $1.97-5.36$ & 9.9 & $2.81^{* *}$ & $1.34-5.88$ & 11.1 & $1.12^{\mathrm{ns}}$ & $0.62-2.00$ \\
\hline Portugal & 0.9 & 1.00 & & 12.5 & 1.00 & & 3.9 & 1.00 & & 9.5 & 1.00 & \\
\hline
\end{tabular}

Note: The first column shows the bivariate analysis, per cent Internet users (chi-square test of group differences; ${ }^{* *} p<.001 ;{ }^{* *} p<.01 ; * p<.05 ; \mathrm{ns}=$ not statistically significant). The second column shows the multivariate logistic regression analysis (adjusted odds ratios (AOR) with $95 \%$ confidence intervals (CI) for using the Internet, weighted data).

In regards to checking out dating sites to find a committed partner, the bivariate contingency tables show that for both men and women, relationship status, satisfaction with current level of sexual activity, and country were statistically significantly related to checking out dating sites to find a committed partner. Sexual activity throughout life was also related to checking out dating sites among men, and masturbation activity among women. The multivariate logistic regression analysis (Table 3-4) showed that checking out dating sites to find a committed partner was 8.4 times higher in Norwegian men and 16.3 times higher in Belgium men compared to men in Portugal. Checking out dating sites to find a committed partner decreased with a factor of 0.91 for every year's 
increase in age in men. Compared to partnered participants, the odds of checking out dating sites to find a committed partner was 6.3 times higher for none-partnered men, and 6.8 times higher for none-partnered women. Compared to women who had never masturbated in the last month, the odds of checking out dating sites to find a committed partner was 2.5 times higher for those who reported monthly masturbation frequency. Furthermore, compared to men with primary education, those with tertiary education had $64 \%$ lower likelihood of checking out dating sites to find a committed partner.

Table 4. The Use of Internet for Love and Sexual Activities in Women, by Selected Predictors $(n=1731)$.

\begin{tabular}{|c|c|c|c|c|c|c|c|c|c|c|c|c|}
\hline & \multicolumn{3}{|c|}{$\begin{array}{l}\text { Checking out dating sites to } \\
\text { find a partner }\end{array}$} & \multicolumn{3}{|c|}{$\begin{array}{l}\text { Read or watch } \\
\text { pornography }\end{array}$} & \multicolumn{3}{|c|}{$\begin{array}{l}\text { Buying sex } \\
\text { products }\end{array}$} & \multicolumn{3}{|c|}{$\begin{array}{c}\text { Seeking sexual } \\
\text { information or advice }\end{array}$} \\
\hline & $\%$ & AOR & $95 \% \mathrm{Cl}$ & $\%$ & AOR & $95 \% \mathrm{Cl}$ & $\%$ & AOR & $95 \% \mathrm{Cl}$ & $\%$ & AOR & $95 \% \mathrm{Cl}$ \\
\hline \multicolumn{13}{|l|}{ Age } \\
\hline $60-64$ years & $3.5^{\text {ns }}$ & & & $3.9^{\text {ns }}$ & & & $5.0^{\text {ns }}$ & & & $5.1^{\mathrm{ns}}$ & & \\
\hline $65-69$ years & 4.8 & & & 3.1 & & & 4.3 & & & 4.6 & & \\
\hline 70-75years & 3.8 & & & 4.3 & & & 4.5 & & & 3.2 & & \\
\hline In one year's increase & & $1.04^{\mathrm{ns}}$ & $0.98-1.11$ & & $1.04^{\mathrm{ns}}$ & $0.98-1.11$ & & $1.01^{\mathrm{ns}}$ & $0.96-1.06$ & & $0.98^{\mathrm{ns}}$ & $0.92-1.03$ \\
\hline \multicolumn{13}{|l|}{ Level of education } \\
\hline Primary & $5.8^{\text {ns }}$ & 1.00 & & $3.4^{\mathrm{ns}}$ & 1.00 & & $4.5^{\mathrm{ns}}$ & 1.00 & & $2.9^{\text {ns }}$ & 1.00 & \\
\hline Secondary & 3.1 & $0.37^{* *}$ & $0.18-0.74$ & 3.5 & $0.69^{\mathrm{ns}}$ & $0.33-1.46$ & 3.7 & $0.56^{\mathrm{ns}}$ & $0.29-1.09$ & 4.2 & $0.97^{\mathrm{ns}}$ & $0.45-2.09$ \\
\hline Tertiary & 4.1 & $0.38^{* *}$ & $0.19-0.77$ & 4.2 & $0.65^{\mathrm{ns}}$ & $0.30-1.39$ & 5.6 & $0.78^{\mathrm{ns}}$ & $0.41-1.51$ & 5.2 & $1.52^{\mathrm{ns}}$ & $0.71-3.28$ \\
\hline
\end{tabular}

\section{Relationship status}

Partnered

Not partnered

$\begin{array}{llllll}2.7^{* * *} & 1.00 & & 3.6^{\mathrm{ns}} & 1.00 \\ 6.8 & 2.26^{* *} & 1.29-3.98 & 4.2 & 1.04^{\mathrm{ns}} & 0.59-1.85\end{array}$
$4.7^{\text {ns }} \quad 1.00$

$4.4 \quad 1.07^{\text {ns }} \quad 0.62-1.85$

$4.4^{\text {ns }} 1.00$

$4.4 \quad 0.96^{\mathrm{ns}} \quad 0.56-1.67$

Sexual activity throughout life

\begin{tabular}{|c|c|c|c|c|c|c|c|c|c|c|c|c|}
\hline Active & $3.5^{\mathrm{ns}}$ & 1.00 & & $3.7^{\mathrm{ns}}$ & 1.00 & & $5.2^{\text {ns }}$ & 1.00 & & $4.3^{\text {ns }}$ & 1.00 & \\
\hline $\begin{array}{l}\text { Neither active nor } \\
\text { inactive }\end{array}$ & 5.9 & $1.49^{\mathrm{ns}}$ & $0.73-3.03$ & 4.4 & $1.14^{\mathrm{ns}}$ & $0.51-2.57$ & 2.9 & $0.48^{n s}$ & $0.19-1.25$ & 4.4 & $0.89^{n s}$ & $0.40-1.97$ \\
\hline Inactive & 5.7 & $1.39^{\mathrm{ns}}$ & $0.60-3.20$ & 6.4 & $2.18^{*}$ & $1.01-4.69$ & 5.0 & $1.15^{\mathrm{ns}}$ & $0.51-2.59$ & 6.4 & $1.59^{\mathrm{ns}}$ & $0.74-3.38$ \\
\hline
\end{tabular}

Number of times masturbated the past month

\begin{tabular}{|c|c|c|c|c|c|c|c|c|c|c|c|c|}
\hline None & $2.7^{* * *}$ & 1.00 & & $2.6^{* *}$ & 1.00 & & $3.6^{* \star *}$ & 1.00 & & $3.7^{*}$ & 1.00 & \\
\hline Monthly & 6.6 & $2.48^{* * *}$ & $1.44-4.29$ & 5.0 & $1.92^{*}$ & $1.08-3.40$ & 6.8 & $2.06^{* *}$ & $1.25-3.37$ & 6.6 & $1.84^{*}$ & $1.11-3.05$ \\
\hline Weekly or daily & 4.3 & $1.59^{\mathrm{ns}}$ & $0.54-4.66$ & 16.3 & $7.51^{* \star *}$ & $3.70-15.25$ & 11.8 & $3.56^{* * *}$ & $1.68-7.54$ & 6.5 & $1.47^{\mathrm{ns}}$ & $0.57-3.80$ \\
\hline
\end{tabular}

Satisfaction with the current level of sexual activity

\begin{tabular}{|c|c|c|c|c|c|c|c|c|c|c|c|c|}
\hline Satisfied & $3.4^{* *}$ & 1.00 & & $4.2^{* *}$ & 1.00 & & $5.7^{*}$ & 1.00 & & $3.9^{* *}$ & 1.00 & \\
\hline Neither nor & 3.4 & $0.69^{\text {ns }}$ & $0.36-1.33$ & 2.2 & $0.45^{*}$ & $0.22-0.89$ & 2.8 & $0.46^{*}$ & $0.25-0.85$ & 3.6 & $0.77^{\mathrm{ns}}$ & $0.42-1.39$ \\
\hline Dissatisfied & 7.5 & $1.39^{\mathrm{ns}}$ & $0.73-2.63$ & 6.3 & $1.18^{\mathrm{ns}}$ & $0.64-2.15$ & 6.0 & $0.85^{\mathrm{ns}}$ & $0.48-1.52$ & 7.8 & $1.58^{\mathrm{ns}}$ & $0.88-2.84$ \\
\hline
\end{tabular}

$\begin{array}{lllllllllllll}\text { Country } & & & & & & & & & & \\ \text { Norway } & 4.9^{* * *} & 2.32^{\mathrm{ns}} & 0.82-6.58 & 4.6^{\mathrm{ns}} & 1.52^{\mathrm{ns}} & 0.58-3.99 & 4.1^{*} & 3.12^{\mathrm{ns}} & 0.81-11.99 & 3.5^{* *} & 0.37^{* *} & 0.18-0.78 \\ \text { Denmark } & 1.9 & 0.89^{\mathrm{ns}} & 0.28-2.86 & 2.7 & 0.96^{\mathrm{ns}} & 0.35-2.67 & 5.9 & 5.55^{*} & 1.48-20.78 & 2.3 & 0.32^{* *} & 0.14-0.73 \\ \text { Belgium } & 6.2 & 2.53^{\mathrm{ns}} & 0.88-7.27 & 4.8 & 1.67^{\mathrm{ns}} & 0.62-4.48 & 5.7 & 5.71^{*} & 1.49-21.83 & 6.3 & 0.74 & 0.36-1.53 \\ \text { Portugal } & 2.2 & 1.00 & & 2.2 & 1.00 & & 1.4 & 1.00 & & 6.8 & 1.00 & \end{array}$

Note: The first column shows the bivariate analysis, per cent Internet users (chi-square test of group differences; *** $p<.001 ; * \star p<.01 ; * p<.05 ; \mathrm{ns}$ $=$ not statistically significant). The second column shows the multivariate logistic regression analysis (adjusted odds ratios (AOR) with $95 \%$ confidence intervals (Cl) for using the Internet, weighted data). 
For 'reading or watching pornography', the bivariate contingency tables show that, in men, all included predictors except relationship status and sexual activity throughout life were statistically significantly related to use of the Internet to watch pornography. In women, masturbation frequency and satisfaction with the current level of sexual activity were bivariately associated with using the Internet to watch pornography. The multivariate logistic regression analysis in men (Table 3) showed that use of the Internet to watch pornography was 3.6 times higher in Norway and 3.3 times higher in Denmark and Belgium than in Portugal. Compared to men who had never masturbated in the last month, the odds of using the Internet to watch pornography were 3.5 times higher for those who reported monthly and 11.3 times higher for those who reported weekly or daily masturbation frequency. Compared to women who had not masturbated the last month, the odds of using the Internet to watch pornography were 1.9 times higher for women who reported monthly $(p<.05)$, and 7.5 times higher for those who reported weekly or daily masturbation frequency (Table 4). Compared to participants who were satisfied with their current level of sexual activity, those who were neither satisfied nor dissatisfied had $46 \%$ lower use of the Internet to watch pornography products $(p<.01)$.

For 'buying sex products', the bivariate contingency tables show that, in men and women, masturbation frequency was statistically significantly related to use of the Internet to buy sex products. In men, satisfaction with the current level of sexual activity and relationship status were statistically significantly related to use of the Internet to buy sex products. The multivariate logistic regression analysis in men (Table 3) showed that use of the Internet to buy sex products was 2.8 times higher in Belgium than in Portugal $(p<.01)$. Compared to participants who had never masturbated in the last month, the odds of using the Internet to buy sex products was 2.3 times higher for men $(p<.001$; Table 3$)$, and 3.6 times higher for women $(p<.001$; Table 4$)$, who reported weekly or daily masturbation frequency.

In relation to 'seeking sexual information or advice', the bivariate contingency tables show that, in both men and women, country was statistically significantly related to use of the Internet to seek information and advice. In women, satisfaction with the current level of sexual activity was significantly associated with using the Internet to seek sexual information and advice. The multivariate logistic regression analysis showed that country was the only significant predictor for both men and women. In men (Table 3) use of the Internet to seek sexual information and advice was $75 \%$ lower in Denmark $(p<.001)$ than in Portugal. The use of the Internet to seek sexual information and advice was $68 \%$ lower in Danish women $(p<.01)$ and $63 \%$ lower in Norwegian women $(p<.01)$ compared to Portuguese women.

\section{Discussion}

This article set out to investigate the prevalence of using the Internet for love and sexual purposes in 60-75-yearold men and women in four European countries, and whether sociodemographic factors and sexual activity could predict this type of Internet use. Older European adults are most likely in the starting pit of using the Internet for love and sexual purposes having previously relied on other outlets for such purposes, e.g. friends or work (Price, Patterson, Regnerus, \& Walley, 2016). In this study, we found that significantly more older-aged European men $(36 \%)$ than women (15\%) had used the Internet for love and sex purposes.

\section{Cross-Cultural Differences}

The present study found that about 1 in 10 women in all countries used the Internet to find a committed partner, seek sexual information or advice, read or watch pornography, or buy sex products. There were few significant cross-cultural differences in usage among women. The bivariate finding that more women in Portugal than in Norway and Denmark had used social media to find a partner for sex may be related to a decreased social network as a consequence of the decreased income after retirement in Portugal.

Among men, however, there were significant cross-cultural differences in usage. The results from the multivariate analyses showed that a lower proportion of men in Norway and Denmark than in Portugal used the Internet to seek sexual information and advice. Also, a lower proportion of men in Portugal than in the other countries used the Internet to check out dating sites, buy sex products, and in particular, to read or watch pornography. The use of pornography has previously been studied in several Nordic countries. For instance, previous Norwegian studies have shown that over $90 \%$ of men and $70 \%$ of women in the general population aged $15+$ years of age report 
lifetime exposure to pornography (Træen \& Daneback, 2012; Træen, Nilsen, \& Stigum, 2006; Træen, Spitznogle, \& Beverfjord, 2004). Both men and women in the Nordic countries (i.e. Denmark and Norway) also tend to express relatively positive attitudes towards pornography (Haavio-Mannila \& Kontula, 2003; Hald, 2006; Hald \& Malamuth, 2008; Lewin, Fugl-Meyer, Helmius, Lalos, \& Månsson, 2000; Træen et al., 2004). Furthermore, people in Norway, Denmark and Belgium have good Internet availability. Taken together, this is probably the most likely explanation for the observed difference in pornographic viewing rates and other Internet activities between Portugal and the other three countries.

\section{Checking Out Dating Sites}

Based on the findings from the multivariate analyses, we found that the use of the Internet to find a committed partner decreased with increasing age in men. One reason for this may be that Internet literacy and usage is generally lower in older age groups (Schreurs, Quan-Haase, \& Martin, 2017). Furthermore, level of education was a unique predictor for using Internet to find a committed partner in both genders. Compared to men and women with primary education, those with tertiary education had lower use of the Internet to check out dating sites. This may reflect that men and women with higher education have other social arenas in which to find partners than the Internet. There may also be different social norms for using the Internet to find a partner for people with low and high education. As 'likes tend to attract likes' (Fugere, Leszczynski, \& Cousins, 2014), men and women with higher education may tend to meet and choose each other as partners to a larger extent than those with very different educational backgrounds. In addition, relationship status predicted use of the Internet to check out dating sites to find a committed partner in both genders. As expected, the odds of using the Internet to seek a committed partner was higher for non-partnered persons compared to partnered participants. An unfortunate consequence of living a long life may be loneliness as a result of losing partners and friends (Heylen, 2010; Yang \& Victor, 2011). For non-partnered older adults, the Internet therefore may offer an arena to find someone to be sexual and share life with (McWilliams \& Barrett, 2012). This may also correspond to the finding that women who masturbated were more likely than women who did not masturbate to use the Internet to find a committed partner. Women who masturbate may have a stronger drive than women that do not to find a partner to love and have sex with.

\section{Reading or Watching Pornography}

In men, the use of the Internet to watch pornography decreased with increasing age. This could likely reflect that sexual interest and activity in men tend to decrease with increasing age (Træen et al., 2017), as well as generally lower Internet use in older age groups (Schreurs et al., 2017).

Men and women who masturbated were more likely than individuals who did not masturbate to use the Internet to watch pornography. Compared to men who were satisfied with their current level of sexual activity, those who were neither satisfied nor dissatisfied reported less use of the Internet to watch pornography. There was a similar tendency among women. Taken together, this indicates the importance of sex in the individuals' lives. Individuals who masturbate frequently may have a higher sex drive or place a higher value on their sex life, which motivated them to watch pornography and get pleasure out of it, as sex is more important to them. This corresponds to studies showing that general use of pornography is more common for highly sexually active individuals (HaavioMannila \& Kontula, 2003; Lewin et al., 2000). Furthermore, in the general population, Træen and Daneback (2012) claimed that men who were dissatisfied with their sex lives may use pornography as a compensation for a malfunctioning sex life, and women's use of pornography seemed to come in addition to an already wellfunctioning sex life. The results from this study indicates that in older age, men and women may be more similar in that pornography tend to be more used among those who are sexually satisfied.

\section{Buying Sex Products and Seeking Information and Advice}

In the questionnaire, examples of sex products to buy on the Internet presented to the participants were sex toys, erotica, Viagra, lubricants, and more. We found that both men and women who masturbated more were more likely to use the Internet to buy sex products than individuals who did not masturbate. Clearly, there exists a group of older adults for whom sexuality is important in life, and they use the Internet to obtain means that will enhance performance and enjoyment. However, it is important to pay attention that buying sex products, as well as seeking 
sexual information and advice, was not significantly explained by any of the included predictors except for country. Internet literacy (Schreurs et al., 2017), and cross-cultural differences in Internet literacy, could be of importance in this respect. For future generations of older adults, it is likely that more than today will find the anonymity, access, affordability, acceptability, and approximation (Cooper, 1998; King, 1999; Ross \& Kauth, 2002), provided by the Internet to buy sex products and seek information about how to manage various sexual difficulties in themselves or their partner, of interest.

Lastly, sexual activity thorough life was not associated with any online sexual activity in women. This could be in accordance with Baumeister (2000) and Baumeister, Catanese, \& Vohs' (2001), hypothesis that women's sexuality is more plastic and dependent on the socio-cultural factors than men's sexuality.

\section{Limitations}

When evaluating the results of this four-country study, some limitations should be considered. From previous research, it is to be assumed that individuals with more liberal views about sexuality were more likely to participate in this study than more traditional individuals (Dunne, 2002). This bias may be reflected in the findings, possibly in overestimated rates of activity on the Internet in relation to the viewing of pornography or perhaps even finding a partner via the Internet as this is still somewhat unusual for older cohorts. Further, although it was emphasized in the recruitment process that the responses from those sexually inactive were as important as from those active, it is possible that sexually active aging men and women are overrepresented in this study (Dunne, 2002), which would, again, inflate our estimates of sexual activity and, highly likely, sexual satisfaction. Some of the measures included in the questionnaire could represent a limitation. For instance, asking only one question about satisfaction with the current level of sexual activity could be misleading for participants, as sexual satisfaction is multidimensional (Štulhofer, Buško, \& Brouillard, 2011). Finally, of the recruited participants, only $0.7 \%$ identified as gay or lesbian, $1.2 \%$ as bisexual, and 3.2\% marked for "other". As the latter category is difficult to interpret, we chose not include sexual orientation in our analyses. Therefore, due to a small number of aging non-heterosexual persons, generalizations of findings to self-identified non-heterosexuals or other sexual minorities may be precluded (de Vries, 2007).

\section{Conclusions}

The present study is one of the few comparative cross-cultural studies with probability samples focusing on sexuality in aging men and women across Europe. By studying how 60-75-year-olds in Norway, Denmark, Belgium, and Portugal use the Internet for sex and love purposes, some interesting implications for future sexual health interventions can be found. Our conclusion is that the Internet is important for many older adults with regard to finding partners, seeking advice, and watching pornography throughout Europe. Given that the coming generations of older adults will be more familiar and competent with using the Internet, our study indicates that there is a great potential for using the Internet for sexual health interventions for older adults across Europe. In addition to serving as an arena to watch and read erotica, websites giving knowledge and advice about sexual issues may help future older adults achieve better sexual health and quality of life. Tailored websites to promote both sexuality and how to preserve a committed relationship are likely to prove important for the aging population.

\section{Acknowledgement}

This research was fully financed by the Norwegian Research Council under the grant number 250637. The last author was supported by the Carlsberg Foundation Distinguished Associate Professor Fellowship. 


\section{References}

Albright, J. M., \& Conran, T. (2003). Desire, love, and betrayal: Constructing and deconstructing intimacy online. Journal of Systemic Therapies, 22(3), 42-53. https://doi.org/10.1521/jsyt.22.3.42.23352

Bargh, J. A., McKenna, K. Y. A., \& Fitzsimons, G. M. (2002). Can you see the real me? Activation and expression of the "true self" on the Internet. Journal of Social Issues, 58, 33-48. https://doi.org/10.1111/1540-4560.00247

Baumeister, R. F. (2000). Gender differences in erotic plasticity: The female sex drive as socially flexible and responsive. Psychological Bulletin, 126, 347-374. http://dx.doi.org/10.1037/0033-2909.126.3.347

Baumeister, R. F., Catanese, K. R., \& Vohs, K. D. (2001). Is there a gender difference in strength of sex drive? Theoretical views, conceptual distinctions, and a review of relevant evidence. Personality and Social Psychology Reviews, 5, 242-273. https://doi.org/10.1207/S15327957PSPR0503_5

Carvalheira, A. (2005). Intimate relationships and sexual behaviours through the Internet (Unpublished doctoral dissertation). University of Salamanca, Portugal.

Carvalheira, A., \& Gomes, F. A. (2003). Cybersex in Portuguese chat rooms: A study of sexual behaviors related to online sex. Journal of Sex \& Marital Therapy, 29, 345-360. https://doi.org/10.1080/00926230390224729

Cooper, A. (1998). Sexuality and the Internet: Surfing into the new millennium. CyberPsychology \& Behavior, 1 , 187-193. https://doi.org/10.1089/cpb.1998.1.187

Cooper, A., Månsson, S.-A., Daneback, K., Tikkanen, R., \& Ross, M. (2003). Predicting the future of Internet sex: Online sexual activities in Sweden. Sexual and Relationship Therapy, 18, 277-291.

https://doi.org/10.1080/1468199031000153919

Cooper, A., Morahan-Martin, J., Mathy, R. M., \& Maheu, M. (2002). Toward an increased understanding of user demographics in online sexual activities. Journal of Sex \& Marital Therapy, 28, 105-129.

https://doi.org/10.1080/00926230252851861

Cooper, A., \& Sportolari, L. (1997). Romance in cyberspace: Understanding online attraction. Journal of Sex Education and Therapy, 22(1), 7-14. https://doi.org/10.1080/01614576.1997.11074165

de Vries, B. (2007). LGBT couples in later life: A study in diversity. Generations, 31(3), 18-23.

DuMouchel, W. H., \& Duncan, G. J. (1983). Using sample survey weights in multiple regression analyses of stratified samples. Journal of the American Statistical Association, 78, 535-543. https://doi.org/10.2307/2288115

Dunne, M. P. (2002). Sampling considerations. In M. W. Wiederman \& B. E. Whitley Jr. (Eds.), Handbook for conducting research on human sexuality (pp. 85-112). Mahwah, NJ: Lawrence Erlbaum Associates, Inc.

Fugere, M. A., Leszczynski, J. P., \& Cousins, A. J. (2014). The social psychology of attraction and romantic relationships. London: Macmillan International Higher Education.

Haavio-Mannila, E., \& Kontula, O. (2003). Sexual trends in the Baltic sea area. Helsinki: The Population Research Institute.

Hald, G. M. (2006). Gender differences in pornography consumption among young heterosexual Danish adults. Archives of Sexual Behavior, 35, 577-585. https://doi.org/10.1007/s10508-006-9064-0

Hald, G. M., \& Malamuth, N. M. (2008). Self-perceived effects of pornography consumption. Archives of Sexual Behavior, 37, 614-625. https://doi.org/10.1007/s10508-007-9212-1 
Heylen, L. (2010). The older, the lonelier? Risk factors for social loneliness in old age. Ageing and Society, 30, 11771196. https://doi.org/10.1017/S0144686X10000292

Eurostat. (2018). Archive: Internet access and use statistics - households and individuals. Retrieved from https://ec.europa.eu/eurostat/statistics-explained/index.php?title=Archive:Internet_access_and_use_statistics__households_and_individuals

Joinson, A. N. (2001). Self-disclosure in computer-mediated communication: The role of self-awareness and visual anonymity. European Journal of Social Psychology, 31, 177-192. https://doi.org/10.1002/ejsp.36

Kim, J., \& Dindia, K. (2011). Online self-disclosure: A review of research. In K. B. Wright \& L. M. Webb (Eds.), Computer-mediated communication in personal relationships (pp. 156-180). New York, NY: Peter Lang Publishing.

King, S. A. (1999). Internet gambling and pornography: Illustrative examples of the psychological consequences of communication anarchy. CyberPsychology \& Behavior, 2, 175-193. https://doi.org/10.1089/cpb.1999.2.175

Lewin, B., Fugl-Meyer, K., Helmius, G., Lalos, A., \& Månsson, S.-A. (2000). Sex in Sweden - On the Swedish sexual life. Uppsala: The National Institute of Public Health.

Malta, S. (2007). Love actually! Older adults and their romantic Internet relationships. Australian Journal of Emerging Technology and Society, 5, 84 -102.

McKenna, K. Y. A., Green, A. S., \& Gleason, M. E. J. (2002). Relationship formation on the Internet: What's the big attraction? Journal of Social Issues, 58, 9-31. https://doi.org/10.1111/1540-4560.00246

McWilliams, S., \& Barrett, A. E. (2012). Online dating in middle and later life: Gendered expectations and experiences. Journal of Family Issues, 35, 411-436. https://doi.org/10.1177/0192513X12468437

Price, J., Patterson, R., Regnerus, M., \& Walley, J. (2016). How much more XXX is Generation X consuming? Evidence of changing attitudes and behaviors related to pornography since 1973. The Journal of Sex Research, 53(1), 12-20. https://doi.org/10.1080/00224499.2014.1003773

Ross, M. W., \& Kauth, M. R. (2002). Men who have sex with men, and the Internet: Emerging clinical issues and their management In A. Cooper (Ed.), Sex and the Internet: A guidebook for clinicians (pp. 47-69). New York, NY: Brunner-Routledge.

Schreurs, K., Quan-Haase, A., \& Martin, K. (2017). Problematizing the digital literacy paradox in the context of older adults' ICT use: Aging, media discourse, and self-determination. Canadian Journal of Communication, 42, 359-377. https://doi.org/10.22230/cjc.2017v42n2a3130

Short, M. B., Black, L., Smith, A. H., Wetterneck, C. T., \& Wells, D. E. (2012). A review of Internet pornography use research: Methodology and content from the past 10 years. Cyberpsychology, Behavior, and Social Networking, 15, 13-23. https://doi.org/10.1089/cyber.2010.0477

Štulhofer, A., Buško, V., \& Brouillard, P. (2011). The new sexual satisfaction scale and its short form. In T. D. Fisher, C. M. Davis, W. L. Yarber, \& S. L. Davis (Eds.), Handbook of sexuality-related measures (3rd ed., pp. 530-532). New York, NY: Routledge.

Træen, B., \& Daneback, K. (2012). The use of pornography and sexual behaviour among Norwegian men and women of differing sexual orientation. Sexologies, 22, e41-e48. https://doi.org/10.1016/j.sexol.2012.03.002

Træen, B., Hald, G. M., Graham, C. A., Enzlin, P., Janssen, E., Kvalem, I. L., . . Štulhofer, A. (2017). Sexuality in older adults (65+)-An overview of the literature, Part 1: Sexual function and its difficulties. International Journal of Sexual Health, 29, 1-10. https://doi.org/10.1080/19317611.2016.1224286 
Træen, B., Nilsen, T. S. r., \& Stigum, H. (2006). Use of pornography in traditional media and on the internet in Norway. The Journal of Sex Research, 43, 245-254. https://doi.org/10.1080/00224490609552323

Træen, B., Spitznogle, K., \& Beverfjord, A. (2004). Attitudes and use of pornography in the Norwegian population 2002. The Journal of Sex Research, 41, 193-200. https://doi.org/10.1080/00224490409552227

Træen, B., Štulhofer, A., Janssen, E., Carvalheira, A. A., Hald, G. M., Lange, T., \& Graham, C. (2018). Sexual activity and sexual satisfaction among older adults in four European countries. Archives of Sexual Behavior. Advanced online publication. https://doi.org/10.1007/s10508-018-1256-x

Wion, R. K., \& Loeb, S. J. (2015). Older adults engaging in online dating: What gerontological nurses should know. Journal of Gerontoligal Nursing, 41(10), 25-35. https://doi.org/10.3928/00989134-20150826-67

Yang, K., \& Victor, C. (2011). Age and loneliness in 25 European nations. Ageing and Society, 31, 1368-1388. https://doi.org/10.1017/S0144686X1000139X

\section{Correspondence to:}

Bente Træen

Department of Psychology

University of Oslo

Box 1094 Blindern

0317 Oslo

Norway

Email: bente.traen(at)psykologi.uio.no

Editorial record: First submission received on April 27, 2018. Revisions received on September 6, 2018, and November 15, 2018. Accepted for publication on November 11, 2018. 


\section{About Authors}

Bente Træen (PhD University of Oslo, 1993) is Professor at Department of Psychology, University of Oslo, Norway). Bente Træen's research interests are (1) use of contraception (2) sexual problems, (3) use of pornography, and (4) sexuality in ageing men and women.

Ana Carvalheira (PhD University of Salamanca, 2006) is Assistant Professor at Department of Clinical Psychology, ISPA - University Institute, Lisbon, Portugal. Researcher at William James Center for Research, ISPA - University Institute). Ana Carvalheira's research interests are shaped by her clinical work as a sexologist. She is interested in studying psychological and socio-cultural correlates of sexual health in the population of adults and older adults. Specific lines of research focus on (1) Female and male sexual response, particularly on sexual desire/arousal, (2) Female and male sexual dysfunctions, (3) the development and testing of mindfulness-based and psychological treatments for women's sexual problems

Ingela Lundin Kvalem, Ph.D. is a professor of health psychology at the Department of Psychology, University of Oslo, Norway. Her research is focused on two key lines of inquiry: 1) body image and ideals from adolescence to old age in relation to sexuality, obesity, and cosmetic surgery, and 2) evidence-based health interventions and behavior change.

Gert Martin Hald (PhD in Psychology, University of Aarhus, Denmark) is an Associate Professor at the Department of Public Health, University of Copenhagen, Denmark where he also head the Section of Environmental Health and research group 'SIR' (The Sexual, Interpersonal Relationships, and Reproductive Health Group. GMH research comprises multiple research projects related to a) Health Sexual Aging, b) Divorce c) Anxiety and Sexuality, and d) Pornography. In 2016 GMH was awarded the Carlsberg Foundation 'Distinguished Associate Professor Fellowship' for the period 2016-2019. GMH also has a background as a clinical psychologist and specialist in clinical sexology. 